\title{
LA-UR-20-30435
}

Approved for public release; distribution is unlimited.

Title: $\quad$ Brief Overview of the ASD Integrated Test Stand, Activities and Hazards

Author(s): $\quad$ Burris-Mog, Trevor John

Zehnder, Geoffrey P.

Intended for: $\quad$ For distribution to institutions and companies supporting the Advanced Sources and Detectors Project.

Issued: $\quad$ 2020-12-23 (rev.1) 
Disclaimer:

Los Alamos National Laboratory, an affirmative action/equal opportunity employer, is operated by Triad National Security, LLC for the National Nuclear Security Administration of U.S. Department of Energy under contract 89233218CNA000001. By approving this article, the publisher recognizes that the U.S. Government retains nonexclusive, royalty-free license to publish or reproduce the published form of this contribution, or to allow others to do so, for U.S. Government purposes. Los Alamos National Laboratory requests that the publisher identify this article as work performed under the auspices of the U.S. Department of Energy. Los Alamos National Laboratory strongly supports academic freedom and a researcher's right to publish; as an institution, however, the Laboratory does not endorse the viewpoint of a publication or guarantee its technical correctness. 


\section{Brief Overview of the ASD Integrated Test Stand, Activities and Hazards}

\section{Trevor Burris, ASD Commissioning Manager \& ITS Technical Lead [NNSS], trevorb@lanl.gov Geoff Zehnder, ASD CAM for ITS and AS\&I [LANL], gzehnder@lanl.gov}

December, 2020

This document includes Pre-CD-2/3 preliminary estimates.

\section{ITS Overview}

The ITS venue provides the first opportunity to fully assemble and test the performance of the injector; integrate, assemble and test four modules; measure the severity of the Beam Break-Up instability and perform the first set of beam measurements. Figure 1 shows a high level configuration of the ITS without the system of overhead cable management trays. The final configuration will integrate the injector, 4 modules (12 accelerator cells), 264 SSPP Line Replaceable Units (LRUs), global controls, data acquisition, and a subset of the downstream transport, Table 1. This was chosen because it provides the minimum accelerator cells required to measure the Beam Break-Up (BBU) instability and perform measurements required to validate the ASD beam transport computer models, which are priority measurements for commissioning.

The ITS venue also provides the opportunity for ASD to validate, optimize and update procedures for assembly, installation and operations along with the first opportunity for NNSS staff to demonstrate proficiency and independence from Laboratory partners. In addition to the integration and operations of major ASD systems, the ITS provides a venue to perform verification and validation testing for a subset of smaller systems and equipment. There is an opportunity to reconfigure and evaluate the Scorpius Safety Interlock System. Virtual Timing and Firing evaluations can also be performed. The amount of testing, however, is bounded by the schedule, and priority activities at the ITS need to be defined by the Technical Director, Commissioning Manager and Technical Leads, ideally before CD-2/3 submittal.
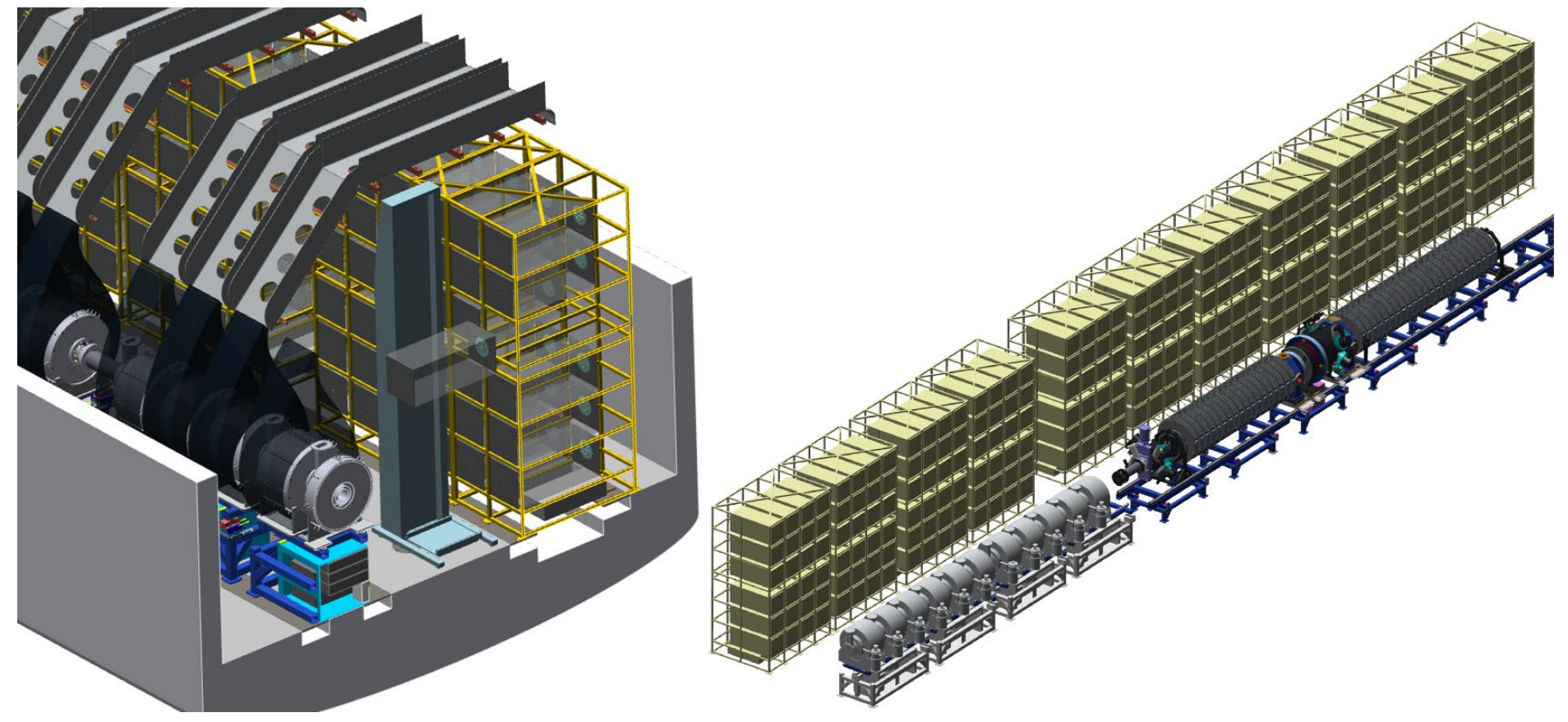

Figure 1: (Left) Conceptual illustration of the Accelerator, Pulsed Power and cable management system. (Right) High level view of the ITS (injector, 4 cell modules and 264 LRUs). 
Schedule Estimate as of October 2020

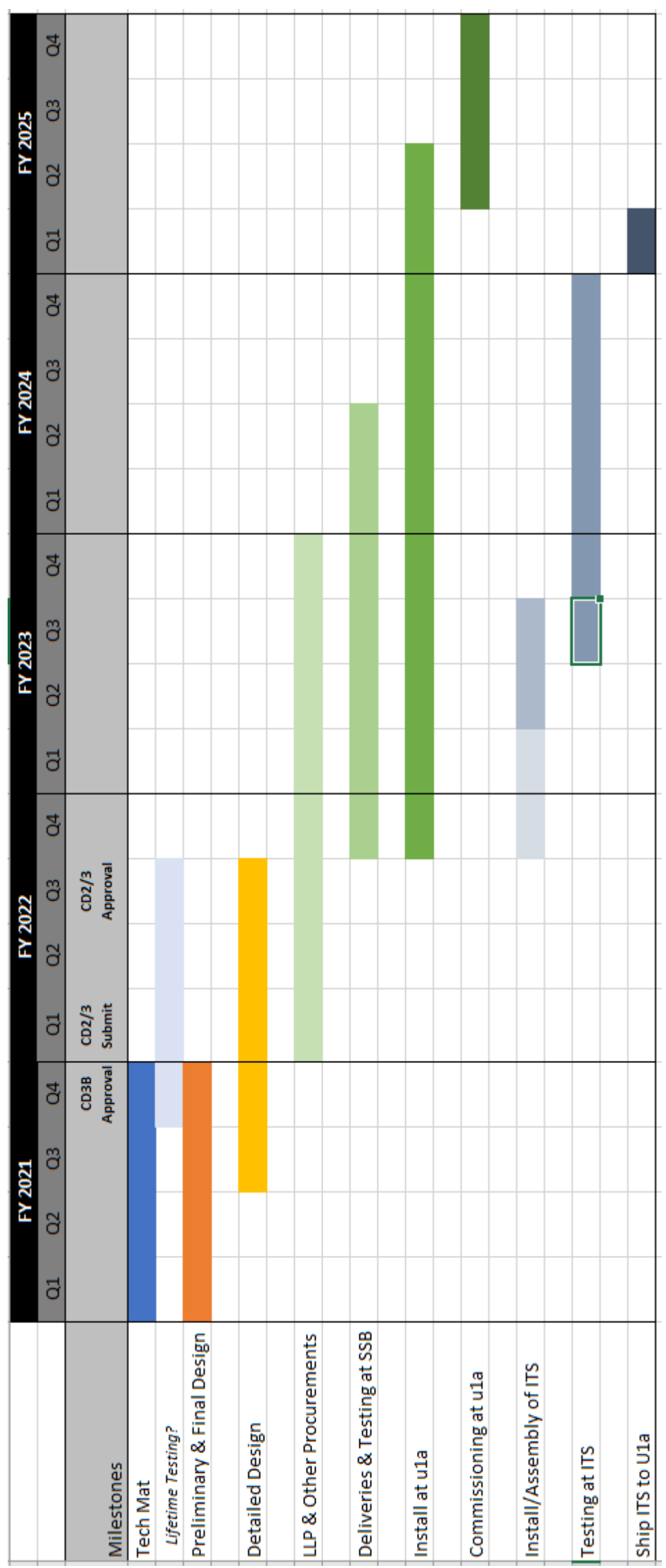


Table 1: List of major components of the ITS, along with diagnostics that will be used during commissioning activities.

\begin{tabular}{|c|c|c|}
\hline $\begin{array}{c}\text { Responsibl } \\
\text { Team }\end{array}$ & System & QTY \\
\hline & SSPP & \\
\hline LLNL & 25 kV Injector LRUs & 168 \\
\hline \multirow[t]{3}{*}{ LLNL } & 25 kV Accelerator LRUs & 96 \\
\hline & Total LRUs & 264 \\
\hline & Pulsed Power Cabling & \\
\hline LLNL & Injector Cables & 1680 \\
\hline \multirow[t]{2}{*}{ LLNL } & Accelerator Cables & 960 \\
\hline & Total Cables & 2640 \\
\hline
\end{tabular}

SNL Injector (full) 1

\begin{tabular}{|lll|}
\hline & Accelerator & \\
LANL & Accelerator Modules (12 cells) & 4 \\
\hline
\end{tabular}

\begin{tabular}{|llr|}
\hline & Global Controls & \\
LANL & Controls and Data Acquisition & Subset \\
\hline
\end{tabular}

\begin{tabular}{|lll|}
\hline & Safety Interlock System (SIS) & 1 \\
NNSS & Reconfigured U1a SIS & 1 \\
\hline
\end{tabular}

\begin{tabular}{|lll|}
\hline & DST & \\
LANL & Beam Stop & 1 \\
LANL & BPM(s) & 2 \\
LANL & Transport Solenoid(s) & 2 \\
LANL & Cruncher & 1 \\
LANL & Spinning Wheel & 1 \\
\hline
\end{tabular}

\begin{tabular}{|clc|}
\hline & Permanently Installed Diagnostics & \\
LANL & BPMs & TBD \\
LANL & Time Resolved OTR Imaging (with actuator) & 1 \\
LANL & Time Resolved Cherenkov Imaging (with actuator) & TBD \\
LLNL & 2 MeV Time Resolved Beam Energy Analyzer & 1 \\
SNL & Pyrometer & 1 \\
\hline
\end{tabular}

\begin{tabular}{|lll|}
\hline & Specialized Diagnostics & \\
LLNL & Slit-Harp & 1 \\
LANL & Tickler & 1 \\
LANL & 4.4 MeV Time Resolved Magnet Spectrometer & 1 \\
LANL & Diamagnetic Loop & 1 \\
LANL & ITS Beam Plug & 1 \\
\hline
\end{tabular}




\section{Installation Activities}

It is assumed that all facility retrofit activities will be complete prior to the installation of ASD systems, hardware and equipment. Installation at the ITS will be challenging due to a number of reasons. The installation of a large number of ASD systems, hardware and equipment will require a detailed logistics plan, with plans in place to adapt to disruptions. The ITS is also one of three synchronous installation activities, with the other two occurring at the Scorpius Support Lab (Area-6, Building 922) and the other at U1a. Lab and NNSS staff will be spread across the three builds in order to complete installations and validation testing. Space for receiving, assembly and temporary storage have yet to be finalized. Table 2 lists the major installation activities.

Table 2: List of major ITS installation activities.

\begin{tabular}{|c|c|c|c|c|c|c|c|c|c|c|c|c|c|}
\hline \multirow{2}{*}{$\begin{array}{c}\text { Responsible } \\
\text { Team }\end{array}$} & \multirow[t]{2}{*}{ Activity } & \multicolumn{12}{|c|}{ Months } \\
\hline & & 1 & 2 & 3 & 4 & 5 & 6 & 7 & 8 & 9 & 10 & 11 & 12 \\
\hline NNSS & Receipt, QA and Non-conformance Activities & & & & & & & & & & & & \\
\hline NNSS & Install Radiation Shielding Enclosure & & & & & & & & & & & & \\
\hline NNSS & Install Facility-ITS Interfaces & & & & & & & & & & & & \\
\hline NNSS & Install A\&SI Interfaces & & & & & & & & & & & & \\
\hline ALL & Validate System Interfaces & & & & & & & & & & & & \\
\hline All & Validate and Update Installation Procedures & & & & & & & & & & & & \\
\hline LANL & Validate U1a Load Handling Equipment & & & & & & & & & & & & \\
\hline LLNL & Install LRU Frames & & & & & & & & & & & & \\
\hline SNL & Install Injector & & & & & & & & & & & & \\
\hline LANL & Install Accelerator Modules & & & & & & & & & & & & \\
\hline ALL & Install Cables & & & & & & & & & & & & \\
\hline LLNL & Install Sub-set of DST & & & & & & & & & & & & \\
\hline NNSS & Perform Alignment & & & & & & & & & & & & \\
\hline LANL & Install Global Systems Hardware & & & & & & & & & & & & \\
\hline LANL & Install Control Room Hardware & & & & & & & & & & & & \\
\hline ALL & Update U1a Installation Schedule & & & & & & & & & & & & \\
\hline NNSS & Install Reconfigured Safety Interlock Systems & & & & & & & & & & & & \\
\hline
\end{tabular}




\section{System Staging and Testing Areas}

In order to operate the ITS, a number of pre-requisite activities and systems validation and verification (V\&V) tests must be performed. V\&V testing will be performed on ASD systems and hardware as it arrives. Staging and test areas are being considered for both A1-4803 and A1-4600. Such plans are only conceptual at this point but will be formally developed in FY21. We do expect three test stands at the ITS: LRU testing, accelerator module testing and SWAT.

The LRU's require vertical and horizontal V\&V testing, and their vertical height of $\sim 10$ feet makes A1-4803 the preferred testing area. Additionally, A1-4803 has cranes that can be used to install the stalk of the LRU, however the height of the LRU Racks limit crane use to outside the radiation shielding enclosure. The injector and accelerator modules will also require a staging area to perform $V \& V$ testing, which may be best suited in situ within the radiation enclosure. Figure 2 illustrates the ITS enclosed within concrete radiation shielding blocks ( 2 foot thick, 10 foot high). Space for a SWAT stand still needs to be determined for the $\sim 10$ foot high injector and accelerator modules, and the area will likely require a keep-out zone.

Figure 2: Concept of LRU staging and V\&V testing area (red outline) in A1-4803.

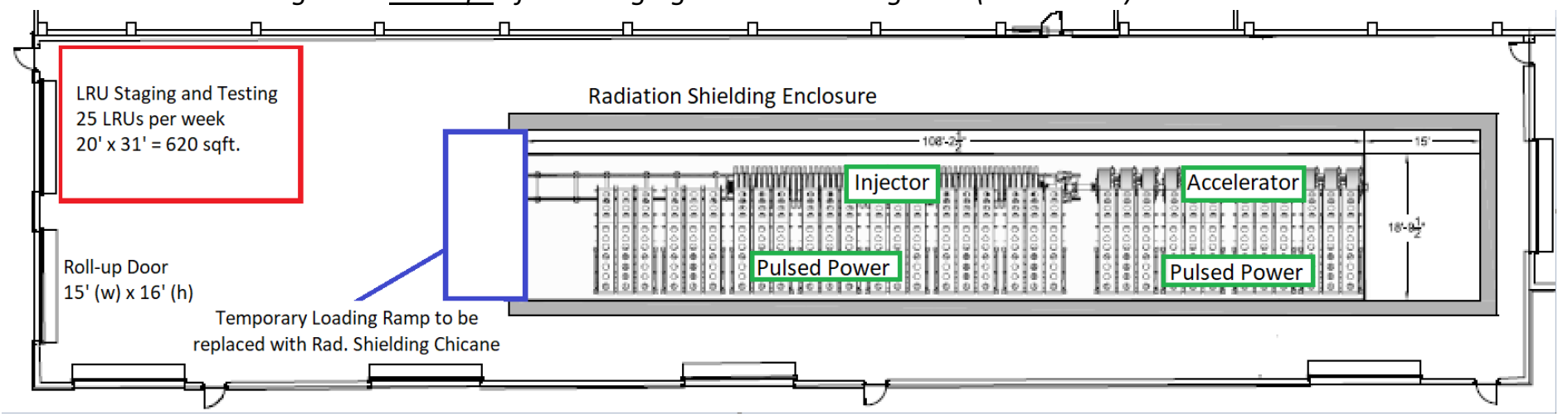

Figure 3: Layout of A1-4600 with conceptual space allocations.

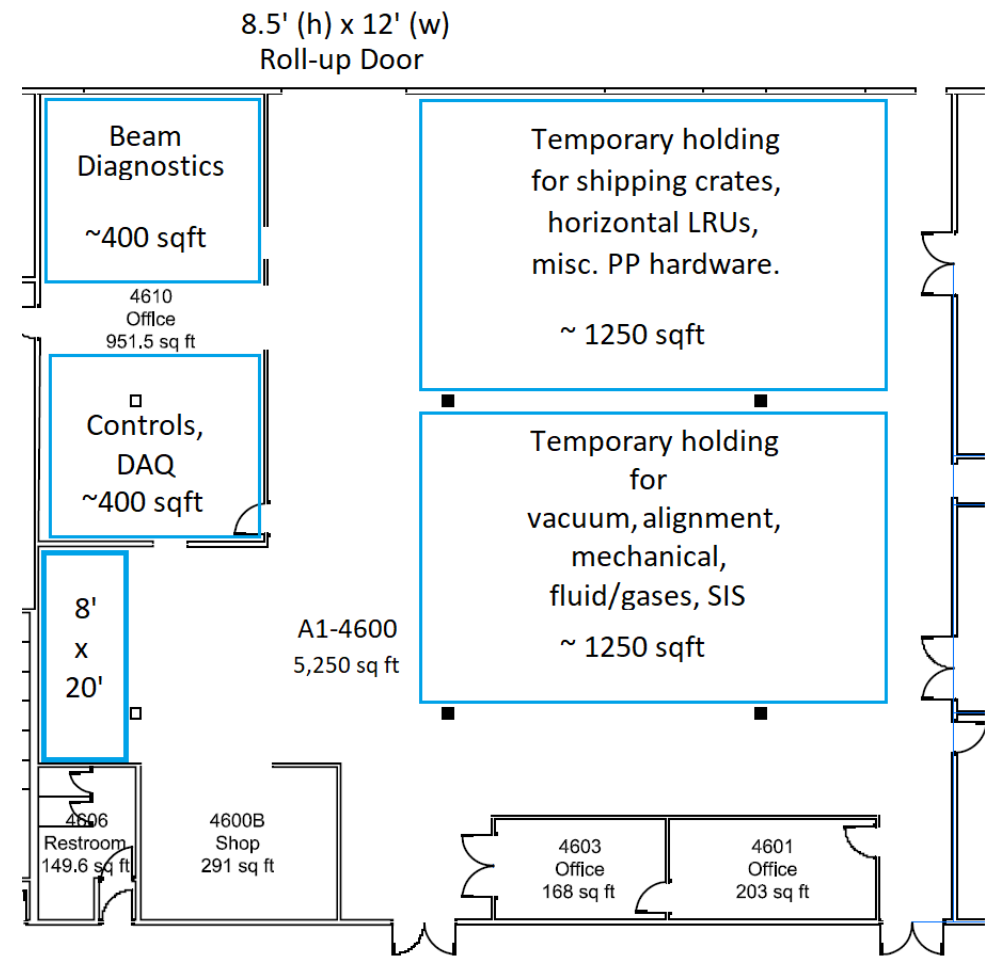




\section{Beam Measurement Activities}

The ITS will generate a $1.45 \mathrm{kA}$ electron beam with a maximum energy of $4.4 \mathrm{MeV}$, which is below the photo-nuclear threshold energy of any nuclide at the ITS. ASD will utilize diagnostics used routinely on other Linear Induction Accelerator, such as DARHT and FXR, to perform beam measurements. The ultimate figure of merit for the Scorpius Accelerator is spot-size and dose, and beam performance parameters have been defined to provide performance criteria at a systems level, Table 3. Table 4 provides a list of integrated testing activities planned for the ITS venue and an initial best-guess of the required time.

Table 3: Beam performance parameters that will be measured at the injector, ITS and Scorpius (these are referred to as KPPs for Scorpius).

\begin{tabular}{|l|l|l|l|}
\hline Performance Parameter & Injector & ITS & Scorpius \\
\hline Beam Current & Yes & Yes & Yes \\
\hline Beam Radius & Yes & Yes & Yes \\
\hline Beam Convergence & Yes & Yes & Yes \\
\hline Beam Centroid Position & Yes & Yes & Yes \\
\hline Beam Emittance & Yes & Yes & Yes \\
\hline Beam Energy (and energy spread) & Yes & Yes & Yes \\
\hline Beam Break-Up Instability & No & Yes & Yes \\
\hline
\end{tabular}

Commissioning of ASD diagnostics at the ITS have not yet been determined. 
Table 4: List of integrated testing activities planned for the ITS venue.

\begin{tabular}{|c|c|c|c|c|c|c|c|c|c|c|c|c|c|}
\hline \multirow{2}{*}{$\begin{array}{l}\text { Responsible } \\
\text { Team }\end{array}$} & \multirow{2}{*}{ Operations Activity } & \multicolumn{12}{|c|}{ Months } \\
\hline & & 1 & 2 & 3 & 4 & 5 & 6 & 7 & 8 & 9 & 10 & 11 & 12 \\
\hline \multicolumn{14}{|c|}{ OPERATIONS } \\
\hline All & Validate/Update Sweep Procedures, Checklists, Walk-Down Procedures, Operations Procedures. & & & & & & & & & & & & \\
\hline ALL & Document Test Deficiencies and Determine Path Forward. & & & & & & & & & & & & \\
\hline NNSS & NNSS personnel to gain operations experience and demonstrate proficiency and independence. & & & & & & & & & & & & \\
\hline \multicolumn{14}{|c|}{ SAFETY INTERLOCK SYSTEM (SIS) } \\
\hline NNSS & Test SIS (Reconfigured for ITS) & & & & & & & & & & & & \\
\hline \multicolumn{14}{|c|}{ INJECTOR } \\
\hline \multirow{3}{*}{ SNL, LLNL } & Validate vacuum system performance, & & & & & & & & & & & & \\
\hline & Cold Cathode Voltage Standoff Testing, & & & & & & & & & & & & \\
\hline & Conditioning and Conditioning Procedure Validation/Updates. & & & & & & & & & & & & \\
\hline \multirow{3}{*}{ LLNL, SNL } & Cathode Activation, & & & & & & & & & & & & \\
\hline & Activation Procedure Validation/Updates, & & & & & & & & & & & & \\
\hline & Pyrometer Measurements. & & & & & & & & & & & & \\
\hline \multirow{4}{*}{ LLNL, SNL } & Beam Generation, Validate/Update Operating Procedures. & & & & & & & & & & & & \\
\hline & Temporal Beam Current and Centroid Measurements (BPMs). & & & & & & & & & & & & \\
\hline & Temporal Beam Transport Measurements ( $R, R^{\prime}$, effect of stimulation emission along anode stalk). & & & & & & & & & & & & \\
\hline & Temporal Beam Energy Measurements. & & & & & & & & & & & & \\
\hline LLNL & Beam Emittance Measurements (measurement uncertainty is TBD). & & & & & & & & & & & & \\
\hline LLNL, SNL & Cathode Power Down (slow and controlled process to safely turn off cathode). & & & & & & & & & & & & \\
\hline \multicolumn{14}{|c|}{ ACCELERATOR } \\
\hline LANL, LLNL & Voltage Standoff Testing, Conditioning and Conditioning Procedure Validation/Updates. & & & & & & & & & & & & \\
\hline LLNL & Mitigate Reflections. & & & & & & & & & & & & \\
\hline NNSS & Operate ITS & & & & & & & & & & & & \\
\hline \multicolumn{14}{|c|}{ GLOBAL CONTROLS } \\
\hline LANL & DAQ Trigger testing (Injector, Accelerator, DST, Pulsed Power, Detector Diagnostics). & & & & & & & & & & & & \\
\hline LANL & Diagnostics Performance (make sure they work). & & & & & & & & & & & & \\
\hline LANL & Virtual Timing and Firing. & & & & & & & & & & & & \\
\hline LANL & Other Global Controls Verification and Validation Activities. & & & & & & & & & & & & \\
\hline \multicolumn{14}{|c|}{ INTEGRATION OF INJECTOR WITH ACCELERATOR } \\
\hline ALL & Couple Injector and LIA & & & & & & & & & & & & \\
\hline \multicolumn{14}{|c|}{ POWER AND THERMAL MANAGEMENT } \\
\hline LANL & A\&SI to evaluate power and thermal management of ASD Systems during the operations of ITS. & & & & & & & & & & & & \\
\hline \multicolumn{14}{|c|}{ COMMISSIONING } \\
\hline NNSS & Beam Generation, Validate/Update Operating Procedures. & & & & & & & & & & & & \\
\hline NNSS & Temporal Beam Current and Centroid Measurements (BPMs). & & & & & & & & & & & & \\
\hline NNSS & Temporal Beam Transport Measurements ( $R, R^{\prime}$, effect of stimulation emission along anode stalk). & & & & & & & & & & & & \\
\hline NNSS & Temporal Beam Energy Measurements. & & & & & & & & & & & & \\
\hline NNSS & Beam Emittance Measurements (solenoid scan). & & & & & & & & & & & & \\
\hline LANL & Cavity Ringdown Spectroscopy & & & & & & & & & & & & \\
\hline NNSS & Diamagnetic Loop & & & & & & & & & & & & \\
\hline
\end{tabular}


List of Hazards

\begin{tabular}{|c|c|c|}
\hline Hazard & Description of Hazard & Mitigation of Hazard \\
\hline Radioactive Materials & None & $\mathrm{N} / \mathrm{A}$ \\
\hline $\begin{array}{l}\text { Radioactive } \\
\text { Contamination }\end{array}$ & None & $\mathrm{N} / \mathrm{A}$ \\
\hline Radioactive Waste & None & $\mathrm{N} / \mathrm{A}$ \\
\hline $\begin{array}{l}\text { Radiation Generating } \\
\text { Devices }\end{array}$ & 4.4 MeV Electron Accelerator & $\begin{array}{l}10 \text { foot high concrete radiation } \\
\text { shielding enclosure, with chicane } \\
\text { entrance and locked gate. The gate } \\
\text { can be interlocked if required. } \\
\text { Operators will sit within sight of the } \\
\text { gate. Administrative and engineering } \\
\text { controls will be developed to follow } \\
\text { NNSS Radiation-Generating Device } \\
\text { Control Program (CD-0441.006). } \\
\text { A Preliminary Personnel Radiological } \\
\text { Exposure Evaluation Report is waiting } \\
\text { for LA-UR review. }\end{array}$ \\
\hline Chemicals & $\begin{array}{l}\text { 1. Ethanol: } 2 \text { quarts } \\
\text { 2. Alcohol wipes: } 25 \text { boxes - } 3 \text { gallons ( } 30-9 \\
\text { inches } \times 9 \text { inches } \times 0.02 \text { inches } 60 \% \\
\text { saturation wipes } 16 \mathrm{~mL} \text { each) } \\
\text { 3. Isopropyl Alcohol: } 4 \text { - } 5 \text { quarts } \\
\text { 4. Sodium Thiosulfate Powder: } 1 / 2 \mathrm{lb} \text {. } \\
\text { 5. Canned Air: } 6 \text { cans } \\
\text { 6. Silicon Putty: } 4 \text { - } 1.25 \text { oz. tubes } \\
\text { 7. Acetone: } 2 \text { quarts } \\
\text { 8. Vacuum Grease: } 2 \text { - } 10 \text { oz. tubes } \\
\text { 9. Sodium Hydroxide: } 1 \text { gallon }\end{array}$ & $\begin{array}{l}\text { Chemicals will be stored in a chemical } \\
\text { storage cabinet. }\end{array}$ \\
\hline Explosives & None & $\mathrm{N} / \mathrm{A}$ \\
\hline Electrical Energy & $\begin{array}{l}25 \text { kV Pulsed Power Line Replaceable Units ( } 264 \\
\text { total) }\end{array}$ & $\begin{array}{l}\text { Engineered access control - please see } \\
\text { mitigation of Radiation Generating } \\
\text { Device above. }\end{array}$ \\
\hline Pressurized Systems & 70 psig & $\mathrm{N} / \mathrm{A},<3,000$ psig \\
\hline Lasers & Fiber Optic Network & $\mathrm{N} / \mathrm{A}$, Class-I, $-\mathrm{II}$ \\
\hline Biohazards & None & N/A \\
\hline Unique Hazards & $\begin{array}{l}\text { Direct Current Magnetic Fields, } 400 \text { G }(0.04 \mathrm{~T}) \\
\text { Max. On-Axis }\end{array}$ & $\begin{array}{l}\text { Engineered access control - please see } \\
\text { mitigation of Radiation Generating } \\
\text { Device above. }\end{array}$ \\
\hline Fire & $\begin{array}{l}\text { 1. A system of cable management trays will } \\
\text { be constructed above the pulsed power } \\
\text { and the accelerator, Figure } 4 \text { (below). The } \\
\text { effectiveness of the fire suppression } \\
\text { system may be decreased. } \\
\text { 2. The injector and accelerator will require } \\
\sim 1000 \text { gallons of oil, either Shell Diala or } \\
\text { ExxonMobil Univolt (NFPA Hazard ID: } \\
\text { Health: 1, Flammability: } 1 \text {, Reactivity: } 0 \text { ). }\end{array}$ & $\begin{array}{l}\text { The fire suppression system may need } \\
\text { to be routed underneath the cable } \\
\text { management trays. }\end{array}$ \\
\hline
\end{tabular}

